\title{
The presence and persistence of entrepreneurship education in Indonesia: a cross sectional study
}

\author{
Ambara Purusottama, Teddy Trilaksono \\ School of Business and Economics, Universitas Prasetiya Mulya, Indonesia
}

\begin{tabular}{l}
\hline \hline Article Info \\
\hline Article history: \\
Received Nov 16, 2018 \\
Revised Jan 5, 2019 \\
Accepted Jan 19, 2019 \\
\hline Keywords: \\
Entrepreneurs \\
Entrepreneurship education \\
Higher education \\
Indonesia \\
Persistent
\end{tabular}

\begin{abstract}
This study aims to improve an understanding of the contribution of entrepreneurship education (EE) in Indonesia's higher education. Even though the contribution of EE to global education is contested at the present time by many scholars, the evaluation of EE implementation in Indonesia is necessary in order to improve educated entrepreneurs. The study used a cross-sectional approach in the Universitas Prasetiya Mulya which is divided into the first, second, and third years. Valid questionnaire reached 924 respondents. The findings show that EE's contribution in Indonesia has more influence on attitudes and perceived behavioral control. However, other findings indicate that the contribution of $\mathrm{EE}$ is still not fully persistent due to a sharp decline in the regression coefficient, especially from subjective norm and perceived behavioral control in the students third year while attitude consistently contributes significant role and has an increasing contribution.
\end{abstract}

Copyright (C) 2019 Institute of Advanced Engineering and Science. All rights reserved.

\section{Corresponding Author:}

Ambara Purusottama,

School of Business and Economics,

Universitas Prasetiya Mulya,

Jl. RA. Kartini (TB Simatupang), Cilandak Barat Jakarta Selatan 12430 Indonesia.

Email: ambara.purusottama@pmbs.ac.id

\section{INTRODUCTION}

Education contributes an important role in enhancing entrepreneurial activity and its competitiveness. Many scholars have shown that education levels are a necessary condition to promote competitiveness [1], [2]. The increase in human capital through education can help create innovation and adaptation to technologies that have implications for income generation [3]. Without improving the quality of education, it will be difficult for a country to improve its economic performance in the long term. The concrete attachment between some activities such as education, job creation, and entrepreneurial performance most certainly confirms the notion that education towards entrepreneurial activities is indeed a vital aspect [4].

\subsection{Contention of entrepreneurship education (EE)}

Given the importance of entrepreneurial contribution to the social and economic community, entrepreneurship education is a key instrument for improving the entrepreneurial attitudes of potential and nascent entrepreneurs [5]. Nevertheless, the presence of entrepreneurship education is still contested. The role of entrepreneurship education has a measurable impact on the intention of entrepreneurship [6]. Entrepreneurship education has a significant impact on student trends and intentionality [7]. On the other hand, other research results tend to assert otherwise that entrepreneurship education has a relatively small impact on entrepreneurial intentions [8], [9]. The difference of educational background does not always have a direct effect towards the student's entrepreneurial intentions [10].

Amid the conflicting arguments of the impact of entrepreneurship education, it is also necessary to study the persistence of the program. Higher the level of education will widen the chances of success of 
entrepreneurs will be [11]. Individuals who have higher entrepreneurship education will have a higher entrepreneurship intention than those who do not [12]. In the meantime, individuals exposed to entrepreneurship education have no effect on entrepreneurial intentions and even tend to be negative [13]. Shortly, the high level of education does not strengthen the relationship with the success of entrepreneurship.

\subsection{Purposes of study}

This research seeks to determine how far the effectiveness of entrepreneurship education process in Indonesia extends towards the desire to engage in business as well as alternative career choice for students from the perspective of Theory of Planned Behavior (TPB). This research is conducted among those in higher education, because college students are seen as the most promising source of entrepreneurship and a place to consolidate the foundations of the organisation that is created [14]. In this study we also measure the persistence of the program by distinguishing the student's level of study. Meanwhile, some previous studies on entrepreneurship education are more prevalent in developed countries and are not widely found in developing countries. In Indonesia, entrepreneurship education research has focused on the concept of entrepreneurship education [15] and its implementation approach [16], [17]. Furthermore, we still have not found a study that evaluates the implementation of entrepreneurship education.

\section{LITERATURE REVIEW}

\subsection{Theory of planned behavior (TPB)}

TPB was developed by Icek Ajzen in 1985 initially to observe human and organizational behavior. In its development, TPB can transform into a theory that helps to predict behavior and is widely used in various disciplines [18]. TPB has been proven empirically to study various forms of behavior [19]. In its early development, TPB accommodates only the subjective attitudes and norms that shape intentions in behavior [20].

Intention is determined by three main factors [19]. First, attitude toward behavior refers to an individual's judgment of the extent to which the behavior is exhibited and also its impact, favorable or not. Attitudes represent the overall evaluation of the behavior undertaken by individuals [18]. The hypothesized attitude component consists of effective (unpleasant/unpleasant) and instrumental evaluation (beneficial/unfavorable) of behavior [21]. Secondly, subjective norms consist of personal beliefs about another person who is considered important to assume that the individual must be involved in behavior or not. The figure in question is an individual whose preference is important. In addition, subjective norms are assumed to assess social pressures on individuals to perform or not through their actions. Measurement of the components of subjective norms can be hypothesized to be both injunctive and descriptive [22]. Finally, perceived behavioral control (PBC) is a perception of the ease or difficulty in performing behaviors and is assumed to reflect past experiences and anticipation of obstacles [19]. These factors include internal control factors (e.g., information, personal shortcomings, skills, abilities, emotions) and external control factors (e.g., opportunities, dependence on others, barriers) [23].

The popularity of TPB has been used in a wide variety of disciplines. TPB helps to predict a person's behavior in their everyday lives [19]. TPB is also widely used to predict consumers' intentions and behavior to buy a product, as in the research conducted by [24], [25]. A meta-analysis study was conducted find the influence of behavior was largely mediated by the strength of behavioral intentions [26].

\subsection{TPB relevance with entrepreneurship and EE}

The power of predicting intent is greater than predicting behavior, because in its course, behavior may change due to other influencing factors [27], [28] In other words, intention does not have to be the same as the action because of the cancellation if, within that period, there is a factor that encourages the cancellation. Intentions have earlier positions than actions. In the context of career choice as an entrepreneur, the TPB concept can also be applied [29].

A career as involving two alternatives: as an entrepreneur or as working in an organization [28]. In relation to the TPB, the intended career decision reflects a process of belief, attitude, and intention of the evolution of congruent capacities of our knowledge, beliefs, and experiences in order to infer the rationality of the use of TPB career choice as an entrepreneur [30]. TPB is a significant predictor of job search intent in addition to the several other variables that affect job seekers [31].

Several other studies have suggested that entrepreneurship education has a significant effect on entrepreneurship [32], [4]. Some cases widely explain the importance of entrepreneurship education in stimulating entrepreneurial intention [33]. Not all agree that $E E$ have a significant impact on entrepreneurship. EE only has a significant impact on those who have never been exposed to the program,

Int. J. Eval. \& Res. Educ. Vol. 8, No. 1, March 2019: 71 - 80 
while it has the opposite effect on those who have received education [6]. EE has no significant effect toward intention to become an entrepreneur. [13], [34].

Education is an important factor in improving the individuals' ability, including entrepreneurial activities. Thus, higher education is believed to provide more benefits. In the context of entrepreneurship, higher education can increase business opportunities compared with those with lower education [35]. Sufficient entrepreneurship education will improve business interest [36]. However, some studies have argued otherwise that the length of study period decreases the desire toward entrepreneurship and interest [34].

\subsection{EE in Indonesia}

Although it has only become a concern in recent years, the application of entrepreneurship education in Indonesia has just started to show its teeth. Through the Indonesian National Education Standards (SNP), entrepreneurship education can be emphasized and given from an early age as stipulated in the Indonesian presidential decree (Perpres) 2005 No. 19 [37]. This effort is carried out in addition to strengthening the nation's economy but also being able to be a stimulus in creating competitiveness for individuals in facing globalization such as the ASEAN Economic Community [38]. In practice, SNP will be a reference for every educational institution in Indonesia to shape the pattern of education and its curriculum so that it can be understood and practiced in daily life [39]. Even though there are many universities that have implemented entrepreneurship education, only a few universities that have dedicated the program into intracurriculum. Those universities include Universitas Prasetiya Mulya, Universitas Ciputra, Universitas Bina Nusantara, Universitas Surya, Institut Teknologi Bandung and several others.

\section{RESEARCH HYPOTHESIS}

The research hypothesis was built using TPB instruments as shown in Figure 1. Attitude (ATT) is a factor in an educated person to get a positive or negative response to earned on entrepreneurial activity, including entrepreneurship [32]. If individuals assume that business is beneficial to him/her, then the individual will respond positively, and vice versa [6]. While in the context of career choice, describes the individual's desire to be self-employment or work within the organization [33]. By definition, attitude represents an evaluation of a psychological object that is captured in the contested attribute dimension, both positive and negative. The shift in confidence can shift because of the valence of beliefs that occur in him at a certain time [19].

Subjective norm (SN) is a measurement instrument of the social pressure felt by individuals in carrying out entrepreneurial activities [5] and refers to the perception of "reference people" to approve decisions or not to become entrepreneurs. $\mathrm{SN}$ is a perception or opinion built from other individuals who are considered important when performing the desired action [40]. When acting as an entrepreneur, the individual will gain influence from another important individual. Career opinions as an entrepreneur or another career will lead individuals to follow particular social pressures [21]. Individual opinions that are considered important for entrepreneurship will influence as a form of social pressure.

Then, the Perception of Behavior Control (PBC) is defined as the perception of ease or difficulty of being an entrepreneur [5]. $\mathrm{PBC}$ is the perception of the ease or difficulty in performing the behavior and is assumed to reflect the past experience and anticipation of obstacles in the future [19]. In Ajzen's theory, it is explained that $\mathrm{PBC}$ is an individual perception that is built regarding the ease and difficulty in carrying out the individual's desires. This perception is built based on a reflection of past experience and also anticipation of future challenges. Confidence of self-efficacy determines how people feel, think, motivate him/her, and behave. In the context of entrepreneurship, these PBC variables relate to the availability of support and resources or obstacles to starting a business [41]. Figure 1 shows diagram of the research hypothesis. 


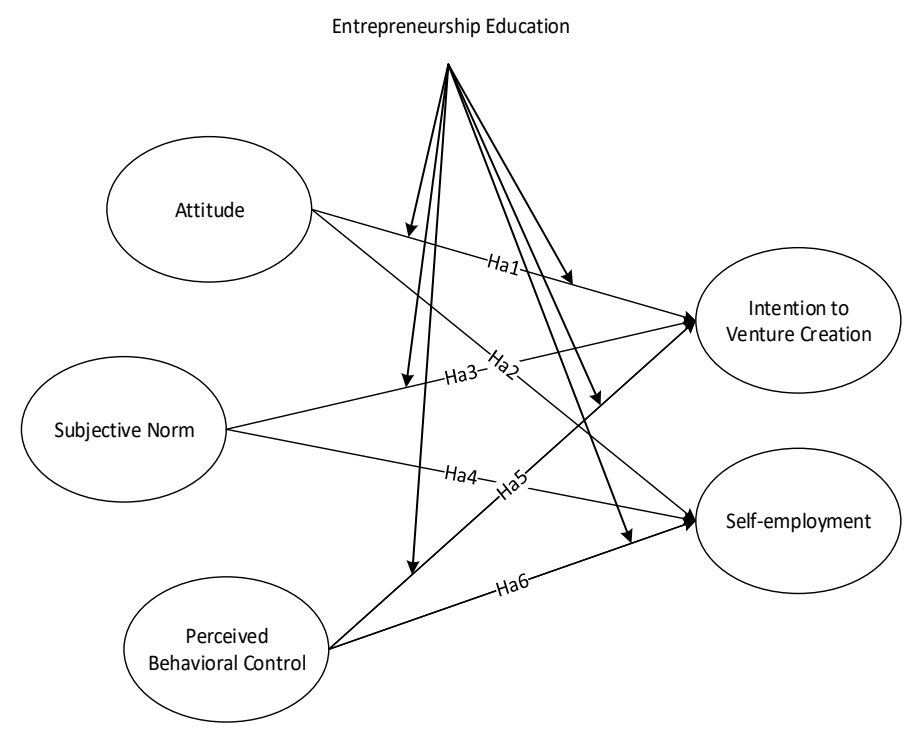

Figure 1. Research hypothesis diagram

\section{RESEARCH METHOD}

\subsection{Sample and research design}

Students are considered to be the most promising source of entrepreneurs [14], and the identification of university students' perceptions of new business intention and feasibilities is the first step to arouse and stimulate university students' interest in entrepreneurial careers. Furthermore, individuals with university education show a greater tendency towards entrepreneurship [42]. Therefore, this study used purposive sampling with cross-sectional method by distributing 956 questionnaires to students who majored entrepreneurship in Universitas Prasetiya Mulya, Indonesia, as shown in Table 1. From all valid questionnaires distributed, 924 were valid. A total of 3.34 percent of unqualified questionnaires were collected.

Table 1. Profile of respondent

\begin{tabular}{llccc}
\hline & & Frequency & Percent & Cumulative Percent \\
\hline Total Participants & & 924 & $100 \%$ & $100 \%$ \\
& First year & 368 & $39.8 \%$ & $39.8 \%$ \\
Level of Study & Second year & 305 & $33.0 \%$ & $72.8 \%$ \\
& Third year & 251 & $27.2 \%$ & $100.0 \%$ \\
\hline
\end{tabular}

To measure ATT toward IVC, research using four items [32], [43], [40]. Students are required to assess whether entrepreneurship and an entrepreneurial career are considered attractive or desirable. Some statements are built to measure attitude.

For measurement of SN, researchers used three items regarding revelation to aid the research [32], [33], [43]. Students were asked to assess how important the people around them are, like family, friends, and other people who are considered important influences on their intention toward entrepreneurship and becoming an entrepreneur.

PBC uses six-item statements to support research [32], [43]. Within the PBC statement construction, the statement contains items that reflect the comfort or discomfort of students to pursue entrepreneurship and become entrepreneurs.

Measurement of entrepreneurial intention and entrepreneurial careen attractiveness uses five and four items of revelation, respectively. Focusing on students' intention to pursue new venture creation and develop interest in becoming entrepreneurs [32], [43], [40]. Table 2 shows the detail of research instrument. 
Table 2. Research instrument

\begin{tabular}{|c|c|c|}
\hline Variable Latent & Statements & Code \\
\hline \multirow{7}{*}{ Subjective Norm } & Being an entrepreneur implies more advantages than disadvantages for me. & ATT_1 \\
\hline & b. Being an entrepreneur makes me proud. & ATT_2 \\
\hline & c. It is desireable for me to become an entrepreneur. & ATT_3 \\
\hline & d. It is interesting for me to become an entrepreneur. & ATT_4 \\
\hline & a. My closest family members think that I should pursue a career as an entrepreneur. & SN -1 \\
\hline & b. My closest friends think that I should pursue a career as an entrepreneur. & $\mathrm{SN}_{2} 2$ \\
\hline & c. People who are important to me think that I should pursue a career as an entrepreneur. & $\mathrm{SN}^{-} 3$ \\
\hline Perceived & a. If I want, I can run my business right now. & $\mathrm{PBC}-1$ \\
\hline \multirow[t]{5}{*}{$\begin{array}{l}\text { Behavioral } \\
\text { Control }\end{array}$} & $\begin{array}{l}\text { b. Others' opinions who claimed I should become an entrepreneur made me more } \\
\text { passionate toward becoming an entrepreneur. }\end{array}$ & PBC_2 \\
\hline & $\begin{array}{l}\text { c. Despite the opinions of those who are against me being an entrepreneur, I will do it } \\
\text { anyway. }\end{array}$ & PBC_3 \\
\hline & d. It is entirely up to me whether or not I become an entrepreneur. & PBC_4 \\
\hline & e. As an entrepreneur, I would have sufficient control over my business & $\mathrm{PBC}^{-} 5$ \\
\hline & $\begin{array}{l}\text { f. There are very few circumstances outside my control that may prevent me from } \\
\text { becoming an entrepreneur }\end{array}$ & PBC_6 \\
\hline Intention to & a. I am ready to do anything to become an entrepreneur. & IVC_1 \\
\hline \multirow[t]{4}{*}{ Value Creation } & b. I will make every effort to start and run my business. & IVC_2 2 \\
\hline & c. I am determined to create my business. & $\mathrm{IVC}_{3} 3$ \\
\hline & d. I have very seriously thought of starting a business. & IVC_4 \\
\hline & e. I have confirmed intention to start a business. & $\mathrm{IVC}^{-} 5$ \\
\hline Professional & a. A career as entrepreneur is attractive to me. & $\mathrm{PA}-\overline{1}$ \\
\hline \multirow[t]{3}{*}{ Attraction } & b. My career goal is to be an entrepreneur. & PA 2 \\
\hline & c. If I had the opportunity and resources, I'd like to be an entrepreneur. & $\mathrm{PA}_{-}^{-} 3$ \\
\hline & d. Among various options, I'd rather be an entrepreneur & PA 4 \\
\hline
\end{tabular}

The statement using 7 Likert-scale points ranges from 1 "strongly disagree" to 7 "strongly agree." Researchers use the Structural Equation Modeling (SEM) as an analytical tool to study the relationship of the variables [44]. This equation uses a reciprocal relationship between the constructs involved in the analysis. The AMOS software is used to analyze the moment structure to estimate the model integrated directly with SPSS.

\section{RESULTS AND DISCUSSION}

\subsection{Validity and reliability}

Data testing is essential before performing data analysis to measure the research model as shown in Table 3. The study uses Kaiser-Meyer-Olkin (KMO) Statistics in data testing. KMO statistics vary from 0 to 1 , indicating the extent to which each variable in a set is predicted without error by another variable [44].

Table 3. Data validity and reliability

\begin{tabular}{|c|c|c|c|c|c|c|c|c|c|c|}
\hline \multirow[b]{2}{*}{ Code } & \multicolumn{5}{|c|}{ Before Adjustment } & \multicolumn{5}{|c|}{ After Adjustment } \\
\hline & $\mathrm{KMO}$ & Sig. & MSA & $\begin{array}{l}\text { Factor } \\
\text { Loading }\end{array}$ & $\begin{array}{c}\text { Cronbach } \\
\text { Alpha }\end{array}$ & $\mathrm{KMO}$ & Sig. & MSA & $\begin{array}{l}\text { Factor } \\
\text { Loading }\end{array}$ & Assessment \\
\hline ATT_1 & & & 0.778 & 0.805 & & & & 0.778 & 0.805 & \\
\hline ATT_3 & 0.145 & 0.000 & 0.709 & 0.89 & 0.884 & 0.145 & 0.000 & 0.709 & 0.890 & 0.884 \\
\hline $\mathrm{ATT}^{-} 4$ & & & 0.73 & 0.877 & & & & 0.730 & 0.877 & \\
\hline SN_- & & & 0.763 & 0.826 & & & & 0.763 & 0.826 & \\
\hline $\mathrm{PB} \overline{\mathrm{C}} 1$ & & & 0.81 & 0.852 & & & & 0.813 & 0.853 & \\
\hline PBC_-2 & & & 0.741 & 0.885 & & & & 0.742 & 0.885 & \\
\hline $\mathrm{PBC}_{-} 3$ & & $0 \Omega 0 \Omega$ & 0.741 & 0.897 & 0660 & 0.745 & 0.000 & 0.740 & 0.897 & 0.774 \\
\hline $\mathrm{PBC}_{-}^{-} 4$ & 0.744 & 0.000 & 0.661 & 0.693 & 0.660 & & & 0.658 & 0.728 & \\
\hline $\mathrm{PBC}_{-}^{-} 5$ & & & 0.668 & 0.696 & & & & 0.668 & 0.719 & \\
\hline PBC_6 6 & & & $0.440^{*}$ & $0.338 *$ & & & & & & \\
\hline $\mathrm{IVC}_{-}^{-} 4$ & & & 0.823 & 0.903 & & & & 0.823 & 0.903 & \\
\hline $\mathrm{IVC}^{-} 5$ & & & 0.848 & 0.891 & & & & 0.848 & 0.891 & \\
\hline PA_ $\overline{1}$ & & & 0.803 & 0.881 & & & & 0.803 & 0.881 & \\
\hline PA_2 & & & 0.776 & 0.885 & & & & 0.776 & 0.885 & \\
\hline $\mathrm{PA}_{-} 3$ & 0.804 & 0.000 & 0.837 & 0.833 & 0.889 & 0.804 & 0.000 & 0.837 & 0.833 & 0.889 \\
\hline $\mathrm{PA}^{-} 4$ & & & 0.809 & 0.873 & & & & 0.809 & 0.873 & \\
\hline
\end{tabular}


Based on the results of the analysis in Table 3, all KMO values fall within the eligible criteria and are considered good $>0.7$. The Bartlett test is then used to test whether the sample $\mathrm{k}$ comes from a population with the same variance, as the adequacy indicator used is 0.05 or 0.001 . The result of Bartlett-test has significant value $(<0.001)$, so the factor analysis is considered appropriate. The value of Measure of Sampling Adequacy (MSA) signifies the correlation strength of an indicator against another. The feasibility of the factor-loading value should at least meet the required standards, which must have a value of $>0.5$ [44]. It can be seen from Table 3 that in the latent variable of PBC, it can be seen that the factor loading value in the PBC_6 variables is below 0.50 . Therefore, the variable can be discarded, because it is considered less suitable for use in measuring the latent variables.

\subsection{Goodness-of-fit model index}

Sample size exceeding 400 respondents makes the Chi-Square (CMIN) and CMIN / DF values unsuitable for measuring the suitability of models with the existing data [44] as shown in Table 4. Root Means Square Residual (RMR) measures the badness-of-fit of a model where the smaller the RMR value, the measured model is rated better and the RMR value has no maximum value. The model of this research has a value of RMR 0.09 which is relatively small and close to 0 , thus the model is in accordance with the data representation. Goodness-of-Fit Index (GFI) indicates a good model in representing the data obtained if it has a value above 0.9. The model shows the results of GFI and Adjusted Goodness-of-Fit Index (AGFI) values close to 1 , although slightly below 0.9 . So it is concluded that the above model is quite good in representing the data obtained in this study.

Table 4. Goodness-of-fit Indicator

\begin{tabular}{lccccc}
\hline Chi-square (CMIN) & NPAR & CMIN & DF & P & CMIN/DF \\
\hline Default model & 51 & 1746.941 & 180 & .000 & 9.705 \\
Saturated model & 231 & .000 & 0 & & \\
Independence model & 21 & 14990.477 & 210 & .000 & 71.383 \\
RMR & RMR $\leq 0,08$ & GFI $\geq 0,9$ & AGFI & PGFI & \\
Default model & .090 & .844 & .800 & .658 & \\
Saturated model & .000 & 1.000 & & & \\
Independence model & .537 & .174 & .091 & .158 & \\
NFI, RFI, CFI, TLI, IFI & NFI $\geq 0.9$ & RFI & IFI $\geq 0.9$ & TLI $\geq 0.9$ & CFI $\geq 0.9$ \\
Default model & .883 & .864 & .894 & .876 & .894 \\
Saturated model & 1.000 & & 1.000 & & .000 \\
Independence model & .000 & .000 & .000 & .000 & .000 \\
RMSEA & RMSEA $\leq 0.08$ & LO 90 & HI 90 & PCLOSE & \\
Default model & .097 & .093 & .101 & .000 & .000 \\
Independence model & .276 & .272 & .280 & & \\
\hline
\end{tabular}

The third measurement uses the Normative Fit Index (NFI) indicator, Relative Fit Index (RFI), Comparative Fit Index (CFI), Tucker Lewis Index (TLI), and Incremental Fit Index (IFI). These models show a good model if the value is close to 1 . The result of the measurement in Table shows that the value of the indicator is close to 1, even though it is below the standard 0.9; this means that the above model is good enough to represent data and theory.

Root Mean Square Error of Approximation (RMSEA) attempts to fix the model mismatch. The RMSEA value between 0.05 and 0.08 indicates a good index for accepting the suitability of a model. However, if the RMSEA value of a model is below 0.1, then the model can be accepted as a good model [44]. As per Table 6, this model can be summarized as a good enough model to represent its data, because the value is close to 0 , despite the number of samples and large data distribution.

\subsection{Hypothesis testing}

\subsubsection{The presence of EE hypothesis}

Based on the hypothesis test, the results vary as shown in Table 5. ATT and PBC variables show a positive and significant relationship to its endogenous variables. Hence, Hypotheses $\mathrm{Ha} 1, \mathrm{Ha} 2, \mathrm{Ha} 5$, and $\mathrm{Ha} 6$ are accepted, because the variable meets the minimum required standard at the $99.9 \%$ confidence level (P $<0.001)$. The SN variable indicates the situation as opposed to its endogenous variables. In relation to IVC, $\mathrm{SN}$ is capable of showing the opposite relationship but with a certain significance. SN can contribute significantly to IVC variables when using a $5 \%$ confidence window $(\mathrm{P}<0.05)$. Ha3 is accepted with a certain

Int. J. Eval. \& Res. Educ. Vol. 8, No. 1, March 2019: 71 - 80 
degree of confidence. However, the relationship between SN and PA shows the correlation relationship and is not significant because it cannot meet the level of trust at which the value is 0.332 . Hypothesis testing on $\mathrm{SN}$ 's relation to PA is unacceptable, or $\mathrm{Ha} 4$ is rejected.

Table 5. The presence of ee hypothesis testing result

\begin{tabular}{ccccccc}
\hline Hypothesis & Relationship & Estimate & S.E. & C.R. & P & Decision \\
\hline Ha1 & ATT ---> IVC & .825 & .069 & 15.626 & $* * *$ & S*** \\
Ha2 & ATT ---> PA & .836 & .063 & 18.216 & $* * *$ & S*** \\
Ha3 & SN ---> IVC & -.119 & .046 & -2.393 & .017 & S* \\
Ha4 & SN ---> PA & -.045 & .044 & -.971 & .332 & NS \\
Ha5 & PBC ---> IVC & .190 & .035 & 4.323 & $* * *$ & S*** \\
Ha6 & PBC ---> PA & .177 & .034 & 4.334 & $* * *$ & S*** \\
\hline (S) Supported; (NS) Not Supported & & \\
* Significant at 0.05 (two-tailed) or 95\% confidence level; ** significant at 0.01 (two-tailed) or 99\% confidence \\
level; *** significant at 0.001 (two-tailed) or 99.9\% confidence levels
\end{tabular}

The result of structural equation test also shows that the ATT variable plays a dominant role in relation to both its endogenous variables. Based on the data, the value of regression coefficient on this equation ATT to IVC is 0.825 and ATT to PA is 0.836 . The PBC variable plays a positive and significant role, but the coefficient value appears smaller than ATT; that is, PBC to IVC (0.151) and PBC to PA (0.147). SN and the exogenous variables have a negative relationship in which the SN is against IVC (-0.119) and (0.45). This situation illustrates the relationship between $\mathrm{SN}$ with both endogenous variables, IVC and PA.

\subsubsection{The persistence of EE hypothesis}

Based on the student's level of study, the results of the hypothesis test tend to vary, as shown in Table 6 when using classification with the control variables of the study level. IVC and PA have a positive and significant correlation, because they meet the established feasibility standard $(\mathrm{P}<0.001)$. Within the relationship between $\mathrm{SN}$ and both endogenous variables there are variations between levels of study. In SN to IVC, positive and significant relationships only occur in first-degree students only. At level two and three, despite the positive relationship, they might not be a significant relationship.

The SN variable has a positive relationship at each level of study, but it does not have a significant relationship because it is unable to meet the required criteria $(\mathrm{P}<0.05, \mathrm{P}<0.01$, and $\mathrm{P}<0.001)$. In the last exogenous variable, $\mathrm{PBC}$, against both exogenous variables, has varied relationships at various levels. PBC's relationship with IVC is only significant in first-year students with $\mathrm{P}<0.001$, while others have no significant relationship. The relationship between $\mathrm{PBC}$ and $\mathrm{PA}$ is consistently positive and significant at each level of study with $\mathrm{P}<0.05$.

Table 6. The persistance of hypothesis testing result

\begin{tabular}{|c|c|c|c|c|c|c|c|c|c|c|}
\hline \multirow{3}{*}{ Hypothesis } & \multirow{3}{*}{ Relationship } & \multicolumn{3}{|c|}{ C.R } & \multicolumn{3}{|c|}{$\mathrm{P}$} & \multicolumn{3}{|c|}{ Decision } \\
\hline & & $1^{\text {st }}$ & $2^{\text {nd }}$ & $3^{\text {rd }}$ & $1^{\text {st }}$ & $2^{\text {nd }}$ & $3^{\text {rd }}$ & $1^{\mathrm{st}}$ & $2^{\text {nd }}$ & $3^{\text {rd }}$ \\
\hline & & Year & Year & Year & Year & Year & Year & Year & Year & Year \\
\hline Hal & ATT ---> IVC & 10.763 & 7.738 & 8.548 & $* * *$ & $* * *$ & $* * *$ & $\mathrm{~S} * * *$ & $\mathrm{~S} * * *$ & $\mathrm{~S} * * *$ \\
\hline $\mathrm{Ha} 2$ & ATT ---> PA & 12.077 & 9.630 & 9.800 & $* * *$ & $* * *$ & $* * *$ & $\mathrm{~S} * * *$ & $\mathrm{~S} * * *$ & $\mathrm{~S} * * *$ \\
\hline $\mathrm{Ha} 3$ & SN ---> IVC & -3.021 & -.417 & -.472 & .003 & .677 & .637 & $\mathrm{~S} * *$ & NS & NS \\
\hline Ha4 & SN ---> PA & -.689 & .045 & -.780 & .491 & .964 & .435 & NS & NS & NS \\
\hline Ha5 & PBC ---> IVC & 4.187 & 1.550 & 1.532 & $* * *$ & .121 & .125 & $\mathrm{~S} * * *$ & NS & NS \\
\hline \multirow[t]{10}{*}{ Ha6 } & PBC $-->$ PA & 2.476 & 2.400 & 1.989 & .013 & .016 & .047 & $\mathrm{~S}^{*}$ & $\mathrm{~S}^{*}$ & $\mathrm{~S}^{*}$ \\
\hline & & & & stimate & & & S.E & & & \\
\hline & Relat & ship & $1^{\mathrm{st}}$ & $2^{\text {nd }}$ & $3^{\text {rd }}$ & $1^{\mathrm{st}}$ & $2^{\text {nd }}$ & $3^{\text {rd }}$ & & \\
\hline & & & Year & Year & Year & Year & Year & Year & & \\
\hline & ATT & IVC & .113 & .113 & .133 & .113 & .113 & .133 & & \\
\hline & ATT & $>\mathrm{PA}$ & .096 & .112 & .120 & .096 & .112 & .120 & & \\
\hline & SN -- & IVC & .090 & .074 & .069 & .090 & .074 & .069 & & \\
\hline & $\mathrm{SN}$ & $\mathrm{PA}$ & .072 & .085 & .071 & .072 & .085 & .071 & & \\
\hline & PBC - & IVC & .061 & .063 & .055 & .061 & .063 & .055 & & \\
\hline & $\mathrm{PBC}$ & $>\mathrm{PA}$ & .049 & .072 & .056 & .049 & .072 & .056 & & \\
\hline
\end{tabular}

The coefficient of the variables consistently demonstrates a positive relationship in all variables. The ATT toward both its endogenous variables, IVC and PA, consistently appears as the dominant coefficient with coefficient values of ATT to IVC (0.113) and ATT to PA (0.096) in the first year, ATT to IVC (0.113) 
and ATT to PA (0.112) in the second year, and ATT to IVC (0.133) and ATT to PA $(0.120)$ in the third year. In the relationship between SN with IVC and PA, variables also consistently have a positive relationship with coefficient value, SN against IVC (0.090) and SN against PA (0.072) in the first year, SN against IVC $(0.074)$ and SN against PA (0.085) in the second year, and SN to IVC $(0.069)$ and SN to PA $(0.071)$ in the third year.

Similar results were also found in the relationship between $\mathrm{PBC}$ with both endogenous variables, IVC and PA, which consistently had a positive relationship with coefficient values, PBC to IVC $(0.061)$ and $\mathrm{PBC}$ to PA (0.049) in the first year, PBC to IVC (0.063) and PBC to PA (0.072) in the second year, and PBC to IVC (0.055) and PBC to PA (0.056) in the third year.

Figure 2 reveals more about the contribution based on the value of regression coefficient shown in the ATT relationship with endogenous variables, namely IVC and PA. The data from the study level indicate an increasing trend, ATT toward IVC, in the first year (0.113), second year $(0.113)$, and last year $(0.133)$ and the relationship between ATT toward PA in the first year (0.096), second year 0.112, and last year $(0.120)$.

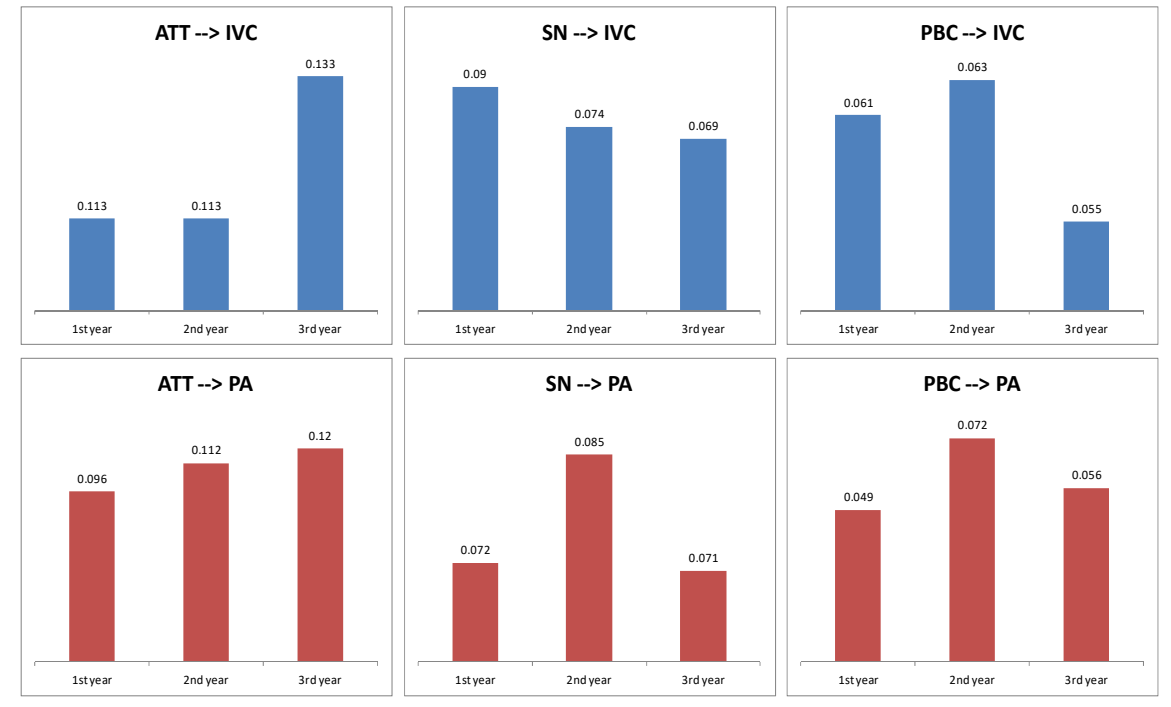

Figure 2. Regression coefficients based on study level

While the relationship of SN with endogenous variables, IVC toward PA, tends to decrease, SN toward IVC, first year (0.090), second year (0.074), and third year (0.069); SN toward PA in the first year (0.072), second year (0.085), and third year (0.071). Finally, the relationship between PBC and other variables tends to interpret relatively random results where PBC toward IVC, first year $(0.061)$, second year (0.063), and third year (0.055); PBC toward PA, first year (0.049), second year (0.072), and third year (0.056).

\subsection{Discussion}

The study found the presence of EE in Indonesia had a positive influence on the intention toward entrepreneurship. The same effect was also felt by students' for a career as an entrepreneur. EE has a positive influence on individuals toward entrepreneurial intention [5], [7]. These findings also support previous research; students had more potential to continue their careers in the field of entrepreneurship [11]-[12]. EE provides an influence from perspective attitude and behavioral control. Entrepreneurship education was considered to provide a positive contribution to students and also considered capable of converting challenges into opportunities for students' entrepreneurship in the future.

Persistence perspective shows that EE consistently gives an increasing students' attitude on entrepreneurial intention. The longer the students are exposed toward entrepreneurship, the more confident and encouraging they are. This situation also applies to the profession of being an entrepreneur. Opposite with [6], entrepreneurship education only has an impact when individuals were exposed EE at the beginning of their education. While from subjective norms and behavioral control, the study found dynamics and tend to fluctuate. Strong influence only felt when the students were in their first year and the rest tend to weaken. Nevertheless, entrepreneurship education was able to provide a strong and persistent influence on behavioral control to become entrepreneurs.

Int. J. Eval. \& Res. Educ. Vol. 8, No. 1, March 2019: 71 - 80 


\section{CONCLUSION}

Although the presence of EE in Indonesia provides a good entrepreneurial influence, it is not yet persistent enough to encourage student's entrepreneurship. Currently, EE's contribution is still limited to attitudes, both the entrepreneurial intention and professional attraction. Student entrepreneurship is more driven by internal factors compared to external factors due to the inappropriate environmental influence and students-perceptions regarding entrepreneurship. EE persistence based on the duration of the study period tends to be questioned especially in the third year even though the influence from outside is quite a lot for students but this gap can be a lesson for curriculum development for the institution concerned.

\subsection{Practical implication}

This study provides many benefits for stakeholders related to EE. For Universitas Prasetiya Mulya, the findings can act as input to the development of academic institutions and related faculty, especially in the development of its learning models and curriculum. For similar educational institutions, proven positive results can be used as a reference in making the curriculum of EE and teaching methods. Furthermore, policy makers can serve as a basis for improvement and development to enhance the role of higher education in the development or formation of superior entrepreneurs, both in terms of quantity and quality [14]. For entrepreneurial activists, entrepreneurship-based education becomes the most promising means to form entrepreneur candidates.

\subsection{Research limitations}

This study has several limitations. Firstly, this research is conducted in Universitas Prasetiya Mulya. Future research can be expected to expand the area of wider area. Second, the cross sectional method therefore the impact cannot provide an overview of the process of EE intervention on student development. Future research will possible to conduct a longitudinal study to give a more comprehensive perspective the role of EE in entrepreneurial process learning.

\section{REFERENCES}

[1] P. Sahlberg and D. Oldroyd., "Pedagogy for economic competitiveness and sustainable development," European Journal of Education Research, Development and Policy, vol. 45(2), pp. 280-299, 2010.

[2] W. J. Mathis., "Is education the key to global economic competitiveness?," Journal the Teacher Educator, vol. 46(2), pp. 89-97, 2011.

[3] T. L. Breton., "The role of education in economic growth: theory, history and current returns," Journal Educational Research, pp. 121-138, 2013.

[4] M. Raposo and A. d. Paço, "Entrepreneurship education: relationship between education and entrepreneurial activity," Psicothema, vol. 23(3), pp. 453-457, 2011.

[5] F. Liñán, J. C. Rodríguez-Cohard, \& J. M. Rueda-Cantuche., "Factors affecting entrepreneurial intention levels: a role for education," International Entrepreneurship and Management Journal, vol. (2), pp. 195-218, 2011.

[6] A. Fayolle and B. Gailly., "The impact of entrepreneurship education on entrepreneurial attitudes and intention: hysteresis and persistence," Journal of Small Business Management, vol. 53(1), pp. 75-93, 2015.

[7] L. Pittaway and J. Cope., "Entrepreneurship education: a systematic review the evidence," International Small Business Journal, vol. 25(5), pp. 479-510, 2007.

[8] T. J. Bae, S. Qian, C. Miao \& J. O. Fiet., "The relationship between entrepreneurship education and entrepreneurial intentions: a meta-analytic review," Entrepreneurship Theory and Practice, vol. 38(2), pp. 217-254, 2014.

[9] R. G. Rodrigue, A. Dinis, A. d. Paço, J. Ferreira \& M. Raposo., "The effect of an entrepreneurial training programme on entrepreneurial traits and intention of secondary students," in Entrepreneurship Born, Made and Educated, Ed. T. Burger-Helmchen, Rjeka: InTech, pp. 77-92, 2012.

[10] Y. Zhang, G. Duysters \& M. Cloodt., "The role of entrepreneurship education as a predictor of university students' entrepreneurial intention," International Entrepreneurship and Management Journal, vol. 10(3), pp. 623-641, 2014.

[11] Doh. S. and McNeely. C. L., "A multi-dimensional perspective on social capital," The Annals of Regional Science, 49(3), pp. 821-843, 2012.

[12] T. Beliaeva, A. Laskovaia \& G. Shirokova., "Entrepreneurial learning and entrepreneurial intentions: a crosscultural study of university students," European Journal of International Management, vol. 11(5), pp. 606-632, 2017.

[13] Oosterbeek H., Praag. M. v., \& Ijsselstein. A., "The impact of entrepreneurship education on entrepreneurship skills," European Economic Review, vol. 54(3), pp. 442-454, 2009.

[14] Veciana. J. M., Aponte. M. S., \& Urbano. D., "University students attitudes towards entrepreneurship: a two countries comparison," International Entrepreneurship and Management Journal, vol. 1(2), pp. 165-182, 2005.

[15] Ghina. A., Simatupang. T. M., \& Gustomo. A., "A systematic framework for entrepreneurship education within a university context," International Education Studies, vol. 7(12), pp. 1-19, 2014. 
[16] Abduh. M., "An evaluation of entrepreneurship education in Indonesia: a case study of bengkulu university," International Journal of Organization Innovation, vol. 4, pp. 21-47, 2012.

[17] Ardianti. R., "Entrepreneurship education in Indonesia's higher education institutions: a solution for problems faced by the next generation," London International Conference on Education, pp. 120-123, 2009.

[18] T. Kautonen. M., v. Gelderen \& M. Fink., "Robustness of the theory of planned behavior in predicting entrepreneurial intentions and actions," Entrepreneurship and Practice, vol. 39(3), pp. 655-674, 2015.

[19] I. Ajzen., "The theory of planned behaviour: Reactions and reflections," Psychology and Health, vol. 26(9), pp. 1113-1127, 2011.

[20] P. A. Pavlou and M. Fygenson., "Understanding and predicting electronic commerce adoption: an extension of the Theory of Planned Behavior," MIS Quarterly, vol. 30(1), pp. 115-143, 2006.

[21] L. C. Tung., "The impact of entrepreneurship education on entrepreneurial intention of engineering students," Hong Kong: City University of Hong Kong, 2011.

[22] M. Manning., "The effects of subjective norms on behaviour in the theory of planned behaviour: A meta-analysis," British Journal of Social Psychology, vol. 48(4), pp. 649-705, 2010.

[23] R. E. Rhodes and K. S. Courneya., "Investigating multiple components of attitude, subjective norm, and perceived control: An examination of the theory of planned behaviour in the exercise domain," British Journal of Social Psychology, vol. 42, pp. 129-146, 2003.

[24] I. Vermeira and W. Verbeke., "Sustainable food consumption among young adults in Belgium: theory of planned behaviour and the role of confidence and values," Ecological Economics, vol. 64(3), pp. 542 - 553, 2008.

[25] A. Tarkiainen and S. Sundqvist., "Subjective norms, attitudes and intentions of finnish consumers in buying organic food," British Food Journal, vol. 107(11), pp. 808-822. 2005.

[26] J. Rise, P. Sheeran \& S. Hukkelberg., "The role of self-identity in the theory of planned behavior: a meta-analysis," Journal of Applied Social Psychology, vol. 40(5), pp. 1003-1291, 2010.

[27] C. L. Shook, R. L. Priem \& J. E. McGee., "Venture creation and the entreprising indiviual: a review and synthesis," Journal of Management, vol. 23(23), pp. 379-399, 2003.

[28] L. Kolvereid and E. Isaksen., "New business start-up and subsequent entry into self-employment," Journal of Business Venturing, vol. 21(6), 866-885, 2006.

[29] J. J. Ferreira, M. L. Raposo, R. G. Rodrigues, A. Dinis, \& A. d. Paço., "Model of entrepreneurial intention: An application of the psychological and behavioral approaches," Journal of Small Business and Enterprise Development, vol. 19(3), pp. 424-440, 2012.

[30] E. A. Hooft, M. P. Born, T. W. Taris, \& H. v. Flier, "Job search and the theory of planned behavior: Minoritymajority group differences in The Netherlands," Journal of Vocational Behavior, vol. 65, pp. 366-390, 2004.

[31] J. Zikic and A. M. Saks., "Job search and social cognitive theory: the role of career-relevant activities," Journal of Vocational Behavior, vol. 74(1), pp. 117-127, 2009.

[32] M. Solesvik, P. Westhead, L. Kolvereid \& H. Matlay., "Student intentions to become selfemployed: The Ukrainian context," Journal of Small Business and Enterprise Development, 19(3), pp. 441-460, 2012.

[33] V. Soutaris, S. Zerbinati \& A. Al-laham, "Do entrepreneurship programmes raise entrepreneurial intention of science and engineering students? The effect of learning, inspiration and resources," Journal of Business Venturing, vol. 22 (4), pp. 566 - 591, 2007.

[34] G. v. Graevenitz, D. Harhoff, \& R. Weber., "The effects of entrepreneurship education," Journal of Economic Behavior \& Organization, vol. 76 (1), pp. 90-112, 2010.

[35] M. Minitti, P. Arenius \& N. Langowitz., "Report on women and entrepreneurship," Babson Park, MA and London: Babson College and London Business School, 2005.

[36] D. Turker and S. S. Selcuk., "Which factors affect entrepreneurial intention of university students?" Journal of European Industrial Training, vol. 33(2), pp. 142-159, 2009.

[37] Peraturan Permerintah Indonesia, "Standar nasional pendidikan, No. 19," Government of Indonesian Republic, Jakarta, 2005.

[38] T. S. Imaroh., "Pendidikan entrepreneurhsip sebagai strategi peningkatan daya saing bangsa dalam menghadapi AEC," Jakarta: Lemhanas, 2014.

[39] Ministry of Education., "Pengembangan pendidikan kewirausahan. Bahan pelatihan penguatan metodologi pembelajaran berdasarkan nilai-nilai budaya untuk membentuk daya saing dan karakter bangsa," Badan Penelitian dan Pengembangan Pusat Kurikulum, 2010.

[40] I. Ajzen., "Consumer attitudes and behavior: the theory of planned behavior applied to consumption decisions," Rivista di Economia Agraria, LXX vol. (2), pp. 121-138, 2015.

[41] N. F. Krueger, M. D. Reilly, \& A. L. Carsrud., "Competing model of entrepreneurial intention," Journal of Business Venturing, vol. 15(5)-(6), pp. 411-432, 2000.

[42] P. D. Reynolds, W. D. Bygrave, E. Autio \& M. Hay., "Global entrepreneurship monitor 2002, executive report," Ewin Marion Kauffman Foundation, Kansas City, 2002.

[43] F. Liñán and Y. Chen., "Testing the entrepreneurial intention model on a two-country," Departament d'Economia de l'Empresa, 2006.

[44] J. Hair, W. Black, B. Babin, R. Anderson, \& R. Tathan., "Multivariate data analysis (Seventh Edition ed.)", Pearson Prentice Hall, New Jersey, 2010.

Int. J. Eval. \& Res. Educ. Vol. 8, No. 1, March 2019: 71 - 80 